О. Ю. Рандалова. Синтез общественных форм в исследовании развивающихся стран ХХ в.

УДК 101.1:316

DOI: 10.18101/1994-0866-2019-1-17-23

\title{
СИНТЕЗ ОБЩЕСТВЕННЫХ ФОРМ В ИССЛЕДОВАНИИ РАЗВИВАЮЩИХСЯ СТРАН ХХ в.
}

\author{
(C) Рандалова Оюна Юрьевна \\ кандидат философских наук, доцент, \\ Бурятский государственный университет им. Д. Банзарова \\ Россия, 670000, г. Улан-Удэ, ул. Смолина, 24а \\ E-mail: oyuna.randalova@gmail.com
}

В статье анализируются исследовательские подходы к проблеме стадиального статуса развивающихся стран. Разработка специфической парадигмы «Третьего мира» в отечественном обществознании шла от идей переходности, многоукладности и зависимости к появлению в 70-80-е гг. концепций «социетарного дуализма» и «общественного синтеза». Автор придерживается мнения о правомерности применения концепции «синтеза традиционного и современного», предложенной востоковедами Н. А. Симония и Л. И. Рейснером, в которой рассматривается ситуация наложения разнородных структур, стадиально различных в результате процесса взаимного влияния Запада и Востока. В работе приводятся исторические примеры, подтверждающие результативность данного методологического подхода. К окончанию эпохи колониализма практически все страны Востока представляли собой комбинированное общество как результат межформационного синтеза в различных вариантах и проявлениях в социально-экономической сфере.

Ключевые слова: неравномерность исторического развития; социальный организм; социум; синтез традиционного и современного; развивающиеся страны; капитализм; колониализм; многоукладность; межсоциумное взаимодействие; Восток.

\section{Для цитирования:}

Рандалова О. Ю. Синтез общественных форм в исследовании развивающихся стран $\mathrm{XX}$ века // Вестник Бурятского государственного университета. Философия. 2019. Вып. 1. С. 17-23.

Неравномерность исторического процесса, различия внутренних ритмов и темпов локальных регионов приводят к взаимодействию социумов, находящихся на различных стадиях развития, к взаимоотношению современного и традиционного в становлении системности человеческого сообщества более высокого уровня. Действие закона неравномерности обусловливает сравнительную высокоразвитость одних социальных организмов и меньшую развитость других в стадиальном плане. Предметом нашего интереса в данной работе являются методологические подходы к изучению взаимодействующих обществ - социальных организмов, находящихся на разных ступенях общественного развития. Понятие «социальный организм» реанимировал Ю. И. Семенов, сделавший его центральным понятием исторического исследования и теоретически обосновавший положение о том, что «история и есть наука о развитии социальных организмов» [9]. Социальный организм - отдельное конкретное общество - носитель формационного качества, «клеточка» истории, которая позволяет обнаружить и проследить действие фундаментальных социологических законов. «В реальной действительности как отдельные самостоятельные образования существуют только социальные организмы, системы социальных организмов, а также вся совокуп- 
ность прошлых и настоящих социальных организмов - человеческое общество в целом» [3]. Другую трактовку отдельного общества предложил Ю. Г. Ершов, вслед за В. И. Израителем используя понятие «социум». Социум в их понимании выражает синтез этнической локальной общности и социального организма систему общественных отношений, обладающую такими свойствами, как целостность, устойчивость, самовоспроизводство [4, с. 62].

Взаимосвязь и взаимодействие социумов усиливаются по мере универсализации технологии человеческой деятельности. По мнению Ю. Г. Ершова, в мировой «цивилизационный» процесс вовлекаются все «реликтовые» и «традиционные» общественные формы, получают мощные импульсы стадиальные сдвиги и процессы преодоления национальной изолированности [4].

В XX в. методологией изучения межсоциумных взаимодействий наиболее активно занимались исследователи развивающихся стран. Именно эти регионы в своем историческом развитии обнаруживают наиболее «выраженные» примеры общественного синтеза в его разнообразных проявлениях. Разработка специфической парадигмы «Третьего мира» в отечественном обществознании шла от идей переходности, многоукладности и зависимости [7] к появлению в 70-80-е гг. концепций «социетарного дуализма» и «общественного синтеза». По мнению М. А. Чешкова, предложившего концепцию «социетарного дуализма», общность развивающихся стран обусловлена характером генезиса, функционирования и трансформации, истоки которых лежат в колониальной эпохе. «Социетарность» означает, что данное образование возникает при контакте различных социальных организмов - капиталистического Запада и «азиатского» по преимуществу Востока. В силу нарушения естественно-исторического хода развития возникшая общность развивающихся стран является искусственно-историческим образованием. «Данное образование конституировано не укладами (социальноэкономическими отношениями разных типов), но социетарными началами собственническим и коллективистским, заданными исторически извне и изнутри, что придает общности дуалистический или неорганический характер» [13]. Поскольку принцип формационности понимается как исторический процесс восходящего, экономически детерминированного и стадийно-дифференцированного движения, вводимые характеристики обществ «Третьего мира» выглядят противоположными формационным - неоднородность развития в пространстве и времени (атемпоральность - астадиальность) вместо стадийной целостности и направленности развития, неорганичность целого, образуемого «взаимодействием двух мировых начал - собственнического и коллективистского», множественность процессов развития по сравнению с однонаправленным характером социального движения формационного типа и т. д. Все это позволяет автору, реконструируя общую теорию развивающихся стран, не только выйти за пределы теории формации, но и подняться на новый надформационный уровень знания.

В центре концепции общественного синтеза, предложенной Н. А. Симонией и Л. И. Рейснером $[11 ; 14]$, рассматривается ситуация наложения разнородных структур, стадиально различных в результате процесса взаимного влияния Запада и Востока. Синтез имеет динамичный характер как движение на более высокий уровень - от докапиталистического состояния к капитализму. Явление синтеза традиционного и современного в развитии стран Востока авторы концепции рассматривают в длительной исторической перспективе - от Средневековья до наших дней. Интересным представляется формационный анализ колониализма. 
О. Ю. Рандалова. Синтез общественных форм в исследовании развивающихся стран ХХ в.

Для этого вводится новое понятие «колониальный синтез», суть которого заключается в том, что на естественно-исторические процессы эволюции стран региона начинают накладываться некоторые последствия естественно-исторического развития европейских метрополий. «По мере утверждения колониализма «почвенное» формационное развитие восточных обществ начинает насильственно укладываться в прокрустово ложе колониально-буржуазного развития, утрачивает историческую инициативу и динамику саморазвития, часть традиционных структур начинает трансформироваться и вовлекаться в колониальный синтез - своеобразное разделение труда в рамках системы метрополия - колония» [14, с. 9].

В условиях независимого развития на базисном уровне в синтезе участвуют три компонента - традиционные структуры, колониальные и неоколониальные структуры, а также национальный капиталистический уклад. Пользуясь сравнительно-историческим методом, авторы приходят к выводу о наличии трех моделей формационного развития капитализма: первичной (прежде всего на родине капитализма - в Англии, а также в ряде других западных стран), вторичной (в основном в странах Центральной и Восточной Европы - в Германии, Италии, России и др.), а также третичной (в современных освободившихся странах). Каждая из этих моделей имеет свои особенности, порожденные неравномерностью развития капитализма как формации в общемировом масштабе, различиями эпох и конкретно-исторических условий и т. п., что предопределило также различные виды государственности.

Капиталистическое развитие в странах вторичной модели происходило под 1) сильным внешним воздействием, 2) при активном вмешательстве внутренней политической надстройки. Во вторичной модели, по сравнению с классической, стадии формационного развития искажаются, так как элементы новой стадии появляются еще до завершения текущей ступени.

Существенно отлична от первичной третичная модель капиталистического развития, для которой характерно то, что она имеет свой генезис (естественноисторический ход развития прерывается, часть традиционных экономических структур, оттесненная на периферию общественной жизни, насильственно вовлекается в синтез с иностранным капиталистическим укладом); колониальный синтез начинался сверху, его генезис и последующие трансформации до обретения национальной независимости определялись метрополией. В результате возникло комбинированное, или многоукладное, общество, состоящее из следующих главных частей: 1) синтез классического колониального типа (мелкотоварное производство, торгово-ростовщический капитал колониальной страны, а также колониальный капитал метрополии); 2) синтез иностранного предпринимательства; 3) национальный капиталистический уклад; 4) остатки традиционного способа производства.

На протяжении всего исторического периода взаимодействия стран Запада и Востока взаимовлияние в сфере хозяйственной экономической жизни было огромным, но особенно в колониальный период процессы синтеза экономических структур были доминирующими.

Актором втягивания восточных обществ в мировое капиталистическое хозяйство являлся промышленный капитал, обнаруживший в своем движении свойство эффективного совмещения и сосуществования с докапиталистическими (традиционными) видами производства в местах и ситуациях, которые обеспечивали быстрый прогресс накопления и высокие нормы прибыли. 
И этот образ действия международного капитала в колониальных странах был неуклонен. Еще Маркс и Энгельс показали, как в последней трети XIX в. машинное производство метрополий, разрушая в колониях и полуколониях ремесла, изменяя традиционное производство и аграрную структуру, принудительно превращало эти страны в рынки сбыта и «места производства соответствующего сырого материала» [8, с. 461]. С этого момента, как пишет Маркс, «создается новое соответствующее расположению главных центров машинного производства международное разделение труда, превращающее одну часть земного шара в область преимущественно земледельческого производства для другой части земного шара как области преимущественно промышленного производства» $[8$, с. 462$]$.

Подобное международное разделение труда вызвало синтезированное производство: промышленность, капитал европейских государств и природные трудовые ресурсы азиатских стран. Например, в аграрной области Азии и Африки трансформация производственных структур в новый тип экономики, в своеобразную систему сочетания традиционного и современного способов производства сводилась к немногим методам: во-первых, «перевести традиционные общинно-крестьянские хозяйства на выращивание экспортных культур: создать мелкотоварное производство в крестьянском секторе, а на базе земельной собственности и аренды - крупное производство помещичьего типа; во-вторых, при благоприятных условиях насадить крупное производство плантационного типа» [14, с. 159].

Что касается последнего, то в начале XX в. оно стало системой синтезированного производства, которое по характеру производственных отношений и способов труда представляло колониально-капиталистический, буржуазный, феодально-рабовладельческий синтез социальной организации труда. Тем не менее аграрные комплексы по производству товарной продукции не стали численно преобладающими. Наиболее массовой и распространенной формой организации колониально-капиталистической экономики являлось мелкотоварное крестьянское производство экспортных культур. Распространился синтезированный тип экономики, когда одновременно производились товарные культуры и продовольствие для собственного потребления, т. е. синтез натуральных и рыночных форм.

Преобладающей тенденцией в эволюции такого типа экономики являлось утверждение буржуазной системы не только сверху, но и «снизу». Вместе с тем представляется правомерным вывод исследователей-востоковедов [6, с. 332] о том, что такое направление развития традиционных структур при преобладании низших и худших форм капитализма не смогло стать доминирующим, что задерживало синтез традиционных и современных отношений в деревне на ранних и средних ступенях.

Своеобразным был процесс капитализации промышленности в странах Востока. Имеется в виду зародившийся синтез традиционного и современного в городской экономике и в несельскохозяйственнных отраслях, который оказался весьма противоречивым и неоднозначным явлением в каждой стране. Определяющим здесь являлся процесс внедрения машинного производства, промышленного капитала, в результате чего вслед за ручным прядением и ткачеством действию их сильной конкуренции подверглись многие традиционные промыслы. Однако сопротивляемость и жизненность традиционных социальных и экономи- 
О. Ю. Рандалова. Синтез общественных форм в исследовании развивающихся стран ХХ в.

ческих структур в городе были очень высокими. Капиталистической промышленности в колониальный период не удалось до конца преодолеть местное экстенсивное мануфактурное производство, которое оставалось и количественно, и пространственно преобладающим. Вследствие этого постепенно формировалась многоукладная система: рядом с количественно преобладающими традиционными способами производства появились элементы капиталистического уклада.

Отмечая явления формационного синтеза, следует обратить внимание на то, что структурный дуализм (сосуществование современного и традиционного в промышленности) формировался в аграрном секторе не столько в процессе естественного поступательного развития, спонтанно, сколько посредством насилия, насаждения «сверху». Поэтому явление общественного синтеза современного и традиционного далеко не всегда и не везде было прочным и перспективным. К примеру, во внутренних глубинных районах, где слабы контакты с большими промышленными городами, традиционные экономические производства «замыкались», оставались прочной основой векового образа жизни, системы образования, социальных отношений, ценностей, управления, унаследованных от докапиталистических общественных отношений. Анализируя генезис капитализма в Сирии, И. М. Смилянская также подтверждала явление нарушения логики формационного развития в результате столкновения и взаимодействия обществ, находящихся на различных уровнях общественной эволюции: «До известной степени независимо существуют отношения, построенные на технических и экономических принципах развитого европейского капитализма, и происходит самовоспроизводство низших форм капиталистического развития, слабо вычлененных из традиционного общества и несущих на себе печать своих цивилизационных особенностей» [10].

С. М. Иванов, исследуя зарождение капиталистических отношений в Османской империи, пишет: «B XIX - начале XX в. периода естественноисторический ход эволюции Османской империи был во многом изменен "сверху" - в результате проведения реформ Танзимата и "извне" - как следствие колониальной экспансии европейских держав. В общественнополитической и экономической жизни империи выстраивались буржуазные политические и экономические учреждения и институты, на выработку которых западноевропейским обществом потребовались целые исторические эпохи» [5]. В результате развитие капиталистических отношений в стране явно ускорилось, но сопровождалось усилением внутренних социально-экономических и политических противоречий и способствовало формированию особого типа исторической эволюции, для которого стало характерным глубокое нарушение генетической целостности и системности развития.

Новый этап в процессах формационного синтеза развивающиеся страны переживали в последней трети XX в. в постколониальных условиях. Уход колонизаторов, обретение национальной независимости и государственности, подъем общественно-культурного движения существенно ослабили процессы насильственного утверждения европейского экономического уклада и окончательного превращения их в составную часть международной капиталистической системы. В результате колониального развития этих стран и вхождения их в орбиту капиталистической системы были получены только гибридные явления - синтезы общественных форм на различных уровнях крупных и малых социумов. 
Экономики таких стран, как Китай, Индия, Мексика, Индонезия, представляли гетерогенные синтезированные системы феодально-капиталистического, патриархально-общинного, капиталистического укладов. И после завершения этапа колониального развития продолжаются процессы межформационного синтеза. В Индии, например, и в настоящее время патриархально-феодальные общины как экономические ячейки, основанные на многосторонней специализации, входят, интегрируются в общую систему товарно-денежных, капиталистических отношений индийского общества. В Мексике большое место в традиционном секторе занимают «эхидо» - коллективные общинные организации, занятые сельскохозяйственным производством и интегрирующиеся с капиталистическими предприятиями и концернами [6, с. 330]. В африканских странах, особенно в Тропической Африке, сохраняются многочисленные кланы, общины, экономические ячейки, и поныне находящиеся на доклассовом первобытно-родовом уровне, и они втягиваются в товарно-денежные капиталистические интеграции, составляя часть причудливого симбиоза африканской экономики. «Как системное целое нынешний базис африканских стран включает в себя не только совокупность местных социально-экономических укладов, но еще и уклады, находящиеся за их национальными и региональными рамками, поскольку связи с ними жизненно необходимы для воспроизводства этих стран» $[1 ; 2]$, — отмечают исследователи-африканисты.

В момент колониального освобождения практически все страны Востока представляли собой комбинированное общество как результат межформационного синтеза в различных вариантах и проявлениях в социально-экономической сфере. Таким образом, шел процесс складывания мировой капиталистической системы, который к 90-м годам прошлого столетия практически завершился формированием глобального капитала. Методологическая эффективность концепции общественного синтеза подтвердилась и при осмыслении более поздних исторических процессов. Так, в работах А. И. Яковлева, посвященных проблеме взаимодействия стран Востока и Запада, в частности в монографии «Страны Востока в условиях глобализации: синтез традиционного и современного», автор использует методологию синтеза традиционного и современного в новых условиях глобализации $[1 ; 15]$. Надо сказать, что концептуализация процесса глобализации, означающей «победу капитала и информационной свободы над национальными интересами, в особенности незападных стран, создание транснациональных систем» [12] все еще продолжается и во многом благодаря тем исследовательским усилиям, совершенными учеными еще в «доглобализационную» эпоху.

Литература

1. Акимов А. В., Яковлев А. И. Цивилизации в XXI: проблемы и перспективы развития. М., 2012. 247 с.

2. Африка. Кланы, классы, общество. М., 1994. 246 с.

3. Диалектика логического и исторического в формационном анализе: доклады координационного совещания по актуальным проблемам теории общественноэкономических формаций / Препринт. М., 1979. 66 с.

4. Ершов Ю. Г. Человек. Социум. История. Свердловск, 1990. 189 с.

5. Иванов С. М. О некоторых чертах переходного периода в условиях Османской империи // Восток в Новое время. М., 1991. 312 с. 
6. Крупные развивающиеся страны в социально-экономических структурах современного мира. М., 1990. 440 с.

7. Левковский А. И. Социальная структура развивающихся стран. М., 1978. 224 с.; Развивающиеся страны: закономерности, тенденции, перспективы. М., 1974. 463 с.

8. Маркс К., Энгельс Ф. Капитал // Маркс К., Энгельс Ф. Сочинения. 2-е изд. М., 1960. T. 23. С. 907.

9. Семенов Ю. И. Категория социальный организм и ее значение для исторической науки // Вопросы истории. 1966. № 8. С. 9.

10. Смилянская И. М. Еще раз о генезисе капитализма в арабских странах (К вопросу о соотношении эндогенных и экзогенных факторов становления капитализма в Сирии в XIX - начале XX в.) // Восток в Новое время. М., 1991. 312 с.

11. Рейснер Л. И., Симония Н. А. Тезисы к общеинститутской дискуссии по проблемам формационного развития стран Востока. М., 1983. 224 с.

12. Федотова В. Г. Хорошее общество. М., 2005. 554 с.

13. Чешков М. А. Восток - «Третий мир»: Идея преемственности и ее критика // Ориентация поиск. Восток в теориях и гипотезах. М.: Наука, 1992. $231 \mathrm{c.}$

14. Эволюция восточных обществ: синтез традиционного и современного. М., 1984. $584 \mathrm{c}$.

15. Яковлев А. И. Страны Востока в эпоху глобализации: синтез традиционного и современного. М., 2015. 392 с.

\section{SYNTHESIS OF SOCIAL FORMS IN THE STUDY OF DEVELOPING COUNTRIES OF THE $20^{\text {th }}$ CENTURY}

Oyuna Yu. Randalova

Cand. Sci. (Philos.), A/Prof.,

Dorzhi Banzarov Buryat State University

24a Smolina St., Ulan-Ude 670000, Russia

E-mail: oyuna.randalova@gmail.com

The article analyzes the research approaches to the problem of the stadial status of developing countries. The development of a specific "Third World" paradigm in domestic social studies proceeded from the ideas of transitivity, multistructurality and dependence to the concepts of "societal dualism" and "social synthesis" that emerged in the 1970-1780s. We stick to the opinion on proper use of the concept of "synthesis of the traditional and the modern", proposed by the orientalists N. A. Simony and L. I. Reisner. It considers the situation of the imposition of heterogeneous structures, which are stadially different as a result of the process of the West and the East mutual influence. The article shows the historical examples confirming the effectiveness of this methodological approach. Researchers of the former colonial countries come to the conclusion that by the end of the era of colonialism almost all countries of the East were by nature a combined society due to the synthesis of various forms and manifestations in the socioeconomic sphere.

Keywords: disparity of historical development; social organism; society; synthesis of the traditional and the modern; developing countries; capitalism; colonialism; multistructurality; inter-societal interaction; the East. 